\title{
ONGELMAPERUSTAISESTA PEDAGOGIIKASTA
}

Opetus rakennetaan tavanomaisesti valmiiden sisältöjen opettelun ja oppiainejaottelun varaan. Ongelmaperustaisen oppimisen idea on, tästä radikaalisti poiketen, oppimisen käynnistyminen autenttisten, ammatillisesta käytännöstä nousevien ongelmien, erilaisten tilanteiden ja teemojen kautta. Laajimmillaan ja parhaimmillaan ongelmaperustainen oppiminen, problem based learning, toteutuu koko opetussuunnitelman tasolla ja opettajan työssä ongelmaperustaisena pedagogiikkana. Kyse on laadullisesti hyvän, jopa erinomaisen oppimisen ja osaamisen tavoittelusta sekä oppijan että opettajan, tässä yhteydessä tutorin, näkökulmasta.

\section{SARI POIKELA}

$\mathrm{K}$

äsittelen lyhyesti joitakin väitöstutkimukseni kannalta keskeisiä kysymyksiä: tie ta, osaamisen kehittymistä ja tutorin työtä tietoympäristönä. Abduktiivinen päättely toimi oman tutkimusprosessini työkaluna mahdollistaen teorian ja empiirisen aineiston käsittelyn sekä analyysin yhtäaikaisena vuorovaikutteisena prosessina. Sama vuorovaikutteisuus toteutuu joustavassa ongelmanratkaisussa. Tutorin osaamista olen tutkinut heidän työssä oppimisensa kautta.

Viime vuosisadalla vaikuttaneen John Deweyn edustaman pragmatistisen filosofian mukaisesti tieto perustuu yksilön tekemiin johtopäätöksiin, jotka pohjautuvat tietyissä tilanteissa tehtyihin havaintoihin ja päätelmiin. Tietoa muodostetaan tietoisen ajattelun lisäksi myös artikuloimattomien ja tiedostamattomien prosessien kautta. Dewey kuvaa yksilön, "mielen“ ja maailman suhteen toiminnallisena yhteytenä, molemmin puolisena sopeutumisena ja orgaanisena vuorovaikutuksena. Oppiminen on ihmisen luonteenomaista toimintaa ja elämisen edellytys. Oppimisen keskeisiksi prosesseiksi voi luonnehtia tutkimista ja ongelmaratkaisua, jotka ovat ongelmaperustaisen oppimisen ydinalueita. Moniin ammatteihin liittyy proseduurinomaisia tehtäviä, jotka on helppo suorittaa. Sekin on osa ammatillista osaamista, mutta vasta monimutkaisten ongelmien ja tehtävien käsittely tuottaa varsinaista ammatillista osaamista. Jack Mezirow käsitteli 1990-luvun kirjoituksissaan ongelmanratkaisun suhdetta kommunikatiiviseen oppimiseen. Siihen sisältyy ulottuvuuksia, joita muotoilevat pitkälti kulttuuriset ja ja kieleen liittyvät koodit sekä sosiaaliset normit ja odotukset, kuten arvot, ideaalit ja aikomukset. Tällöin ongelmanratkaisun logiikka perustuu metaforiin ja abduktioon. Se eroaa selkeästi hypoteettis-deduktiivisesta logiikasta, jossa ongelmanratkaisun pohjana on abst-

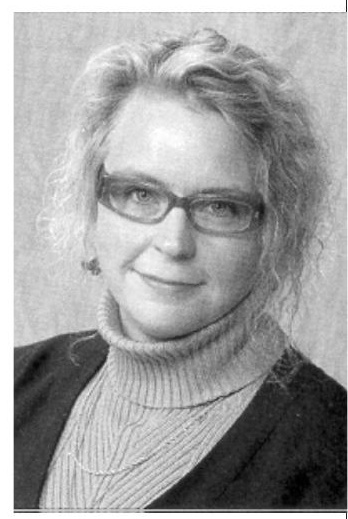

Sari Poikela raktit periaatteet ja teoriat, joista edetään kohti konkretiaa. Abduktiiviseen logiikkaan perustuvassa ongelmanratkaisussa liikutaan sen sijaan konkreetista abstraktiin ja jälleen abstraktista konkreettiseen. Ongelmanratkaisu aloitetaan assosiaation ja elaboraation avulla eli selvittämällä, mitä aiheesta jo tiedetään ja miten sitä tulkitaan tämän hetkisen tietämyksen valossa.

Deduktion ja induktion voi nimetä modernismin aikaansaannoksiksi. Molemmat tekevät selkeän jaottelun mielen (englanninkielinen termi mind) ja maailman (englanniksi world) välillä ja molemmat ovat siksi luonteeltaan dualistisia. Mieli sijaitsee yksilön sisäpuolella, kuin pään sisällä, ja maailman sijainti on selkeästi yksilön ul- 
kopuolella. Voidaanko tällaista erottelua ylipäätään tehdä? Abduktiossa mieli ja maailma nähdään kyllä käsitteellisesti erillisinä, mutta ne ovat toisiinsa sidottuja perustavanlaatuisessa keskinäisessä vuorovaikutuksessa. Abduktiivinen tiedonkäsittely ei ole sidottu kieleen, vaan syntyy kielen ulkopuolella. Siksi sitä on varhaisessa vaiheessaan helpompi kuvata ikonisena tai mielikuvallisena ilmiönä. Lopullisessa muodossaan abduktio kuitenkin tukeutuu sanalliseen muotoon. Vasta prosessin viimeisessä vaiheessa muoto on systematisoitunut ja käsitykset ovat löytäneet paikkansa osana kokonaisuutta. Abduktio on yhdistelmä sosiaalista ja individuaalista, koska käsitykset testataan ja auktorisoidaan sosiaalisesti. Peirce käytti 1950-luvulla juuri abduktiota kuvatessaan käsitysten syntyä ja piti abduktiota deduktioon ja induktioon verrattuna huomattavasti tehokkaampana käsitteellistämisen tapana. Hänen mukaansa abduktio on metaforinen prosessi, joka pitää sisällään yhtä aikaa sekä vanhan että uuden merkityksen.

Deweyn mukaan yksilö verifioi käsityksiään nimenomaan laadullisten ja toiminnallisten ulottuvuuksien kautta. Aikaisemmat skeemat, symbolit ja käsitykset muuntuvat uusiksi käsityksiksi ja tiedoksi suhteessa kokemuksiin ja toimintaan. Tähän kytkeytyy myös kehollinen elementti.

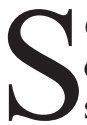
euraavaksi käsittelen lyhyesti tiedon ja osaamisen suhdetta. Tärkeää on, mitä on saavutettavissa hyvän koulutuksen avulla sekä mikä puolestaan on ammatillisen toiminnan avulla saavutettavissa olevaa taitoja ja osaamista. Ongelmaperustaisessa oppimisessa lähtökohtana toimivat ongelmat heijastelevat työelämän reaalimaailmaa. Opetuksen tavoite on ohjata ongelmanratkaisua niin, että oppija kykenee integroimaan teoreettista ja käytännöllistä tietoa sekä yksilöllisissä että ryhmässä jaetuissa tiedon muodostuksen prosesseissa. Integraation tuloksena syntyy kokemuksellista tietoa, joka on luonteeltaan pysyvämpää kuin muistamiseen tai emotionaalisiin elämyksiin perustuva tieto.

Tähän kytkeytyy osaamisen kehittyminen. Informaatio voi olla mitä tahansa eri aistien kautta kohdattavaa tietoa. Teoreettinen tieto puolestaan on käsitteellistettyä symbolista informaatiota, joka saa on merkityksensä yksilön oman mentaalisen prosessoinnin kautta. Praktinen, käytännöllinen tieto on luonteeltaan konkreettista, kuten esimerkiksi organisaation rakenne. Myös se tar- vitsee prosessointia saadakseen merkityksen. Teorian ja käytännön välinen liike tuottaa kokemuksellista tietoa. Sitä pystyy luomaan ainoastaan oppija itse. Kokemus ei siis ole sama asia kuin käytäntö, kuten arkipäiväisessä ajattelussa oletetaan. Kokemus saa laajan merkityksen, kuten myös Dewey korostaa.

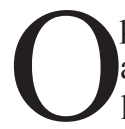
ppiminen ja osaaminen ovat kontekstuaalisia ja ajallisesti muuntuvia. Ammatillisen osaamisen tuottaminen merkitsee paljon muuta kuin ammatillisen tiedon perusteiden tarjoilemista. Oppijan on kyettävä koulutuksen avulla saavuttamaan myös hiljaisen tiedon elementtejä. Se mahdollistuu luomalla samankaltaisuutta koulutuksen ja työn maailmojen välille. Oppiminen jatkuu työssä ja erityisen tärkeää onkin, miten ammatillista ja organisationaalista osaamista hyödynnetään työyhteisössä.

Mitä merkitystä näillä tiedon muodostuksen ja käsittelyn teorioilla sekä osaamisen pohdinnoilla sitten on tämän vuosituhannen vaihteen suomalaiselle ja tamperelaiselle kasvatustieteelliselle tutkimukselle? Tarkastelen tutkimuksessani fysioterapian ja lääketieteen opettajien osaamisen kehittymistä ongelmaperustaisen pedagogiikan soveltajina, ohjaavina tutoreina ja heidän työnsä keskeisiä elementtejä. Tutkimuksen empiirinen aineisto on koottu vuosina 1995-1997 ja 2001. Ongelmaperustaisen pedagogiikan tavoitteena on tuottaa koulutuksen sisältöön liittyvien substanssitaitojen lisäksi myös prosessiosaamista kuten ongelmanratkaisutaitoja, kykyä tiimityöhön ja vuorovaikutukseen, valmiuksia analyyttiseen ja kriittiseen ajatteluun. Tutkimustulosteni perusteella samojen taitojen kehittyminen muodosti myös tutorin, opettajan työssä oppimisen ytimen. Keskeiset kysymykset olivat:

- miten tutorit hankkivat ja käsitteellistivät ammatilliselle kehitykselleen välttämätöntä tietoa työssään?

- miten tutorien osaaminen kehittyy ongelmaperustaisen pedagogiikan kontekstissa?

Tutorin työn tietoympäristön kokoavassa analyysissa sovelsin Blacklerin 1990-luvulla esittämää tiedon lajien tyypittelyä kooditettuun, ankkuroituun, sisäistettyyn, kehollistettuun ja kulttuuristettuun tietoon. Symbolista, kooditettua tietoa edustivat esimerkiksi erilaiset ohjeet ja mallit. Tutoreille tätä edusti erityisesti ongelmaperustaisen oppimisen syklimalli. Työssä oppimisen näkökulmasta symbolisen tiedon olomuodot toi- 
mivat organisationaalisen oppimisen lähteinä, jotka vähitellen integroituivat koko työyhteisön yhteiseksi omaisuudeksi.

Ankkuroituun, esineellistettyyn tietoon puolestaan kytkeytyi muun muuassa toimiminen erilaisissa tehtävärooleissa organisaatiorakenteissa sekä kysymykset resursseista. Esimerkiksi miten hyvin opetustilat soveltuvat siihen, että useampi tutoriaali-istunto toteutetaan pienryhmissä samaan aikaan ja miten järjestetään jokaiselle ryhmälle tutor-opettaja?

Sisäistetty, käsitteellistetty tieto on olennainen osa tutorin ammatillisen kehittymisen ja osaamisen ydintä. Kyse on vuosia kestävästä työssä oppimisesta. Alkuvaiheessa tutorit pitivät työtapojensa ja ohjaajan roolinsa muutosta vaikeana. Osa heistä kaipasi tuttua ja turvallista sisällön asiantuntijan roolia. Tähän liittyi huoli, että opiskelijat oppisivat varmasti kaiken tarpeellisen, ja halu selittää asiat mahdollisimman perusteellisesti. Vuosien myötä tutorien tuntemukset kääntyivät lähes päinvastaisiksi ja tutorina toimiminen olikin mielekkäämpää kuin asiantuntijaluentojen pitäminen. Toisaalta erilaisissa rooleissa toimittiin entistä joustavammin, eikä niiden tilannesidonnaista vaihtelua koettu yhtä pulmalliseksi kuin alussa. Tutorin toiminnan avainsanoiksi nousivat rohkeus, luottamus ja odottaminen.

Kaikkia osaamisen osa-alueita oli vaikea pukea sanalliseen muotoon. Silloin oli kyse kehollistetusta, toiminnallistetusta tiedosta. Sitä voidaan ymmärtää Nonakan määrittämänä hiljaisena tietona tai Schönin ammatillisena taitamisena, jota hän kuvaa artistry -käsiteellä. Tutorit kuvasivat itseään vaikuttajina, joiden tehtävä on luoda vahva ja hyvä ilmapiiri. Oli kuitenkin vaikea pukea sanoiksi sitä, mitä kaikkea tämä piti sisällään.

Aineistoni ilmensi laajaa, koko oppilaitosta koskettavaa muutosta liittyen ongelmaperustaisen opetussuunnitelman rakentamiseen ja siihen siirtymiseen. Yhteisesti tuotetulla ja prosessoidulla kulttuurisella tiedolla oli tärkeä merkitys muutoksessa. Organisaation toiminnassa kollektiivisen kulttuurisen tiedon saattaminen sanoiksi oli vaikeaa, kuten se on yksilöillekin. Tässä olivat apuna metaforat ja vertaukset. Siihen liittyi sosiaalinen vuorovaikutus ja yhteisesti jaettu tieto, jota voi kuvata esimerkiksi kollektiivisena organisaatiossa vallitsevana tunnetilana.

Kulttuurista tietoa voi verrata organisationaaliseen oppimiseen, joka alkaa intuition muodostumisesta. Tämä prosessi vertautuu abduk- tiiviseen tiedonmuodostukseen. Yksilön ja ryhmien toiminnan lisäksi kulttuurisella tiedolla on merkittävä rooli, koska suurin osa työyhteisön hiljaista tietoa kytkeytyy juuri organisationaaliseen kulttuuriin. Sitä on mahdollista yrittää avata, ymmärtää ja hyödyntää ainoastaan yhteisissä oppimisen prosesseissa. Organisaation ulkopuolisella tutkijalla on silloin käyttöä hiljaisen ja potentiaalisen tiedon tulkkina, fasilitaattorina ja voimistajana. Tulkintani ja tutkimustulokseni ilmentävätkin, että ongelmaperustainen pedagogiikka, joka loi tutorin työlle kehyksen, mahdollisti jatkuvan ammatillisen kasvun ja osaamisen kehityksen yksilöllisesti, yhteisöllisesti ja organisationaalisesti.

Lectio praecursioria 14.6.2003

KL Sari Poikelan väitöstutkimus Ongelmaperustainen pedagogiikka ja tutorin osaaminen tarkastettiin Tampereen yliopistossa 14. kesäkuuta vastaväittäjänä professori Pauli Kaikkonen

Jyväskylän yliopistosta.

Sari Poikela on syntynyt Tampereella 1967 ja suorittanut kasvatustieteiden lisensiaatin tutkinnon Tampereen yliopistossa 1998. Hän on Tampereen yliopiston kasvatustieteiden tiedekunnan Edutainstituutin projektipäällikkö.

Poikelan väitöskirja on myös sähköisenä sarjassa Acta Electronica Universitatis Tamperensis, http:// acta.uta.fi. Väitöskirjan tilausosoite:

Verkkokirjakauppa Granum, http://granum.uta.fi, tai Tampereen yliopiston julkaisujen myynti, (03) 215 6055, e-mail: taju@uta.fi. 